\title{
Internet of Things Based Smart Medicine Mobile Application
}

\author{
Azra Nur Gür ${ }^{*}$, Eda Saydam², Zeynep Öztemur ${ }^{3}$, Mustafa Alper Akkaş ${ }^{4}$ \\ 1* Bolu Abant İzzet Baysal Üniversitesi, Mühendislik Fakültesi, Bilgisayar Mühendisliği Bölümü, Bolu, Türkiye (ORCID: 0000-0003-0361-0325), \\ nurrgur@gmail.com \\ ${ }^{2}$ Bolu Abant İzzet Baysal Üniversitesi, Mühendislik Fakültesi, Bilgisayar Mühendisliği Bölümü, Bolu, Türkiye (ORCID: 0000-0002-2251-4980), \\ sydmeda12@gmail.com \\ ${ }^{3}$ Bolu Abant İzzet Baysal Üniversitesi, Mühendislik Fakültesi, Bilgisayar Mühendisliği Bölümü, Bolu, Türkiye (ORCID: 0000-0003-2899-1240), \\ zeynepoztemur-b@tubitak.gov.tr \\ ${ }^{4}$ Bolu Abant İzzet Baysal Üniversitesi, Mühendislik Fakültesi, Bilgisayar Mühendisliği Bölümü, Bolu, Türkiye (ORCID: 0000-0003-0185-0464), \\ alperakkas@ibu.edu.tr
}

(3rd International Congress on Human-Computer Interaction, Optimization and Robotic Applications June 11-13, 2021)

(DOI: $10.31590 /$ ejosat.954526)

ATIF/REFERENCE: Gür, A. N., Saydam, E., Öztemur, Z. \& Akkaş, M. A. (2021). Internet of Things Based Smart Medicine Mobile Application. European Journal of Science and Technology, (26), 117-121.

\begin{abstract}
Technological developments in recent years bring important effects in the health sector as well as in all sectors. However, the global population is aging, the number of chronic diseases is increasing, and there is also an increase in health expenditures and patient drug use. This situation significantly affects access to health and puts emphasis on developing technology by bringing issues such as speed, quality and cost into the agenda in the field of health. Internet of Things supported devices provide the opportunity to keep patients safe and healthy by making it possible to monitor them remotely in the healthcare sector. In addition, thanks to the remote monitoring of patients, the follow-up of drug use is made more easily and the efficiency of the treatment is increased. In this study, in the context of the issues mentioned above, information was given about the general literature on the Internet of Things of and especially the tracking of drug use in the field of health, and the Smart Drug Tracking Application, developed for the purpose of tracking drugs in line with the personal data of the users, was technically explained.
\end{abstract}

Keywords: Internet of Things (IoT), Health Information Systems, Medical Devices, Drug Tracking System, Covid19.

\section{Nesnelerin İnterneti Tabanlı Akılıı İlaç Mobil Uygulaması}

Öz

Son yıllarda yaşanan teknolojik gelişmeler tüm sektörlerde olduğu gibi sağlık sektöründe de önemli etkileri beraberinde getirmektedir. Bununla birlikte, küresel nüfus yaşlanmakta, kronik hastalıkların sayısı artmakta ve sağlık harcamalarında ve hastaların ilaç kullanımında da artış meydana gelmektedir. Bu durum sağlığa erişimi önemli ölçüde etkilemekte ve sağlık alanında hız, kalite ve maliyet gibi hususları gündeme getirerek gelişen teknolojiye vurgu yapmaktadır. Nesnelerin interneti destekli cihazlar sağlık sektöründe uzaktan izlemeyi mümkün kılarak, hastaları güvenli ve sağlıklı tutma olanağı sunmaktadır. Bunun yanı sıra, hastaların uzaktan takip edilebilmesi sayesinde ilaç kullanımının takibi de daha rahat yapılmakta ve tedavinin verimi de arttırılmaktadır. Bu çalışmada yukarıda ifade edilen hususlar bağlamında nesnelerin interneti ile ilgili genel literatür ve sağlık alanında özellikle ilaç kullanımının takip edilmesi konusunda bilgi verilmiş, kullanıcıların kişisel verileri doğrultusunda ilaç takibinin yapılabilmesi amacıyla geliştirilmiş Akıllı İlaç Takip Uygulaması teknik olarak açıklanmıştır.

Anahtar Kelimeler: Nesnelerin İnterneti (IoT), Sağlık Bilgi Sistemleri, Medikal Cihazlar, İlaç Takip Sistemi, Covid19.

\footnotetext{
*Corresponding Author: nurrgur@gmail.com
} 


\section{Introduction}

According to the definition of the World Health Organization, the drug defines as "the product used to change or examine physiological systems and pathological (disease causing) conditions for the benefit of the user"(Cingi,1996). In recent years, drug use has become arguably the most important part of the healthcare industry. After the pharmaceutical revolution in the medical sector, drug consumption has increased rapidly due to the factors that every segment of the society can benefit from health services more easily, drugs are more accessible compared to the past, and the demand for drugs has also increased. In addition, many negative factors such as environmental pollution, smoking, alcohol, increased consumption of harmful foodstuffs and stress facilitated the emergence of new diseases, which triggered an increase in consumption. (Özata et al., 2008: 530) The fact that diseases that could not be cured in the past years can now be treated, especially in today's advanced technology, has led to the introduction of many new drugs to the pharmaceutical industry. The increase in drugs and treatment methods has also increased the drug consumption once again.(A.Y1lmaztürk, 2013)The fact that diseases that could not be cured in the past years can now be treated, especially in today's advanced technology, has led to the introduction of many new drugs to the pharmaceutical industry. The increase in drugs and treatment methods has also increased the drug consumption once again. (Özata et al., 2008: 530)

With this project, we aim to take the drug treatment process of patients under control. With a smart medicine box, we track whether the patient takes their medication or not, and if not, we send a reminder notification to the mobile phone application. Thus, we prevent disruption in the treatment process or short-term drug use of diseases such as diabetes, heart, COPD, alzheimer, blood pressure, dementia ("Drug Use Behaviors", 2009).

\section{Literature Study}

Internet of Things (IoT); can be defined as a network structure where devices or machines send data, collect information and decide with the collected information without the need for human intervention, it is the situation where objects used in daily life can exchange data with other objects via the internet and these objects are in complete synchronization with each other. Advances in information, telecommunications and network technologies play an important role in healthcare and contribute to the development of medical information systems. With the convergence of medicine and information technologies, healthcare services are also entering a transformation process and their outputs are decreasing costs, decreasing inefficiencies and most importantly, prolonging life expectancy (Dimitrov, 2016). Nowadays, the increasing use of smart devices and communication applications in monitoring healthcare professionals, patients and the health sector are also increasing. (Sezer, 2018) Industrial objects have an healthcare services and their effects on the activities of attractive impressive effect of the health sector country. In other words, medical care services and health services have attractive application areas for the IoT. IoT provides important applications such as remote health monitoring, fitness programs, chronic diseases and care. In addition, home treatment and compliance is another important practice for healthcare professionals. In this case, various medical devices, sensors and diagnostic and imaging devices can be counted as Smart devices or objects (Islam et al., 2015). IoT in Health; Provided to take control of health and safety by sharing critical patient information and providing written devices and sensors in relevant resources. In this process, you can obtain data flow between smart phone devices, data related to devices and electronic devices for real-time patient imaging such as vital signs.

\section{Materials and Methods}

\subsection{Technologies and Methods}

The aim of developing the smart medicine box project is to ensure that patients who are using drugs can take their medicines regularly and correctly thanks to the application and medicine box we have developed. Software, database and technology options that we can use for the development of the project have been investigated. A mobile application has been designed so that users can easily access the platform to be developed anytime and anywhere. The first prototype of the system was implemented on the Android operating system, for this Android Studio, an Android software development environment, was used. Java language was used as the programming language in Android Studio. Android is an open source mobile operating system developed by Google, the Open Handset Alliance and the free software community. The developed software model has been executed and stored on GitHub (GitHub, 2021). Thanks to the Git version control system, it provides convenience for software developers to work in cooperation. At the same time, the changes made to the application software are continuously monitored.The health component we use for our project is the medicine box. Our medicine box works with the Bluetooth Module system. After the drug intake status is indicated with the button, it will be transferred to the application via the bluetooth module. Thus, data communication between the application and the drug box will be provided by bluetooth.

Firebase platform developed by Google was used for recording and storing data in the system (Firebase, 2021). The most important point of the advantages of the Firebase environment is that it can work quite compatible with the Android environment. At the same time, high resource access is one of its plus aspects. In addition to its free usage opportunity, Firebase supports applications such as application management, usage tracking, data storage, sending notifications without the need to write another server or server-side code

\subsection{Intelligent Drug Box and Drug Tracking System}

In the design of the smart medicine box, it consists of 2 main sections, medicine and alarm, so that medication can be monitored every day of the week and every meal (morning-noon-evening) in a controlled manner. The medicine section includes 21 medicine compartments on the left front of the box. Alarm part consists of Buzzer, LCD screen and Button. The drug information taken from the box is provided with the button. Audible warning signals are sent with the buzzer system on the medicine box. An example of a smart medicine box is shown in Figure 1. 


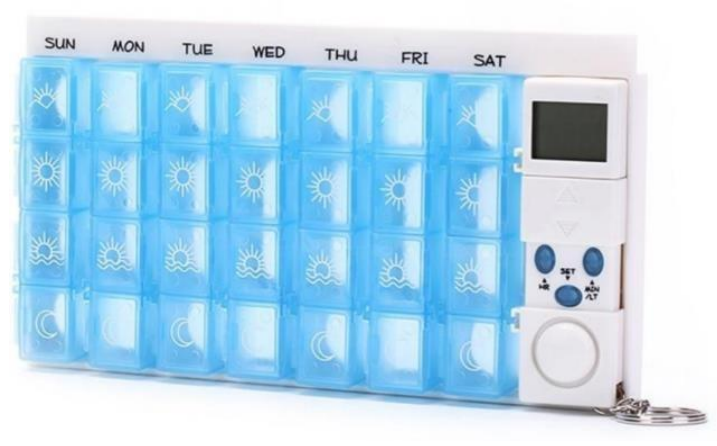

Figure1. Example of Smart Medicine Box

With the smart medicine box, the medication follow-up of the patients will be able to be followed in a controlled manner. In the system we have developed, medication will be monitored without the application, together with the box. When the patient's medication time comes, the buzzer on the box will start to ring. Simultaneously, a notification will be sent to the user's phone from the application. In case the patient presses the button after taking their medication, the buzzer will stop playing and send the medication receipt information to the application. The flow chart of the project is shown in Figure 2.

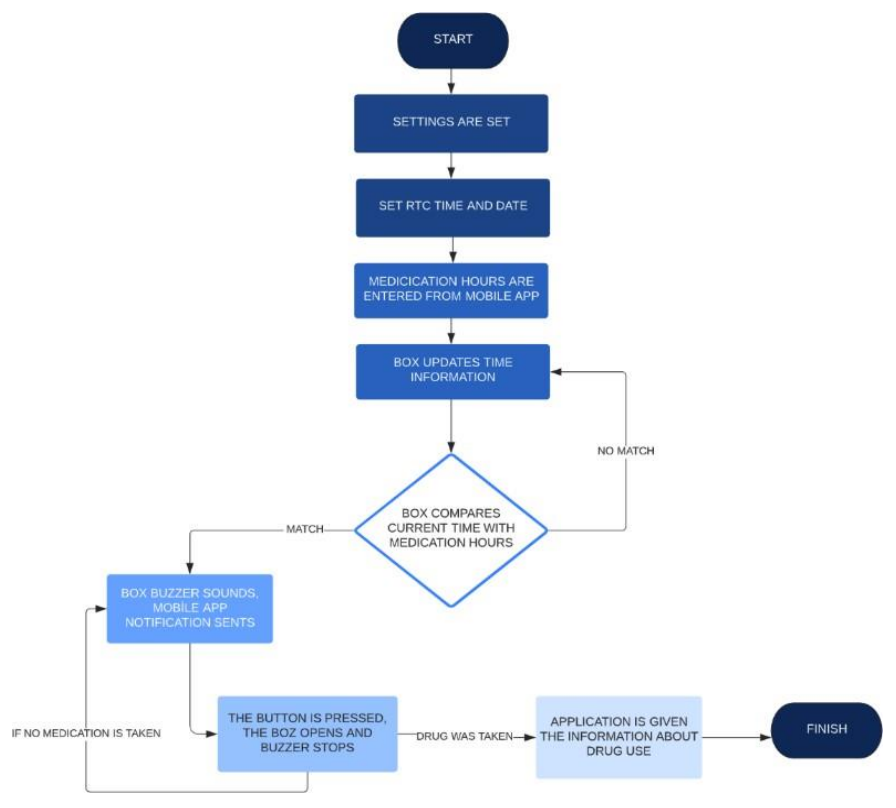

Figure2. Flow Chart Of The Project

\subsubsection{Backend Development}

While developing the backend, firstly, researches were made on the database, which is the most necessary part of the program to work as desired, and the Google Firebase database was selected and installed. Firebase is a very advanced database that can be integrated with Android applications and has a real-time database feature. Firebase session was opened for the project and integrated with the Smart Pill Box project found in Android Studio. When entering the application, it is necessary to register with your email and password information. For this, users are listed and followed from the Firebase Login section. A database model has been created to keep user information and drug information in relation to each other in the Firebase environment. The database structure created in the Firebase environment for the Smart Pill Box project is shown in Figure 3.

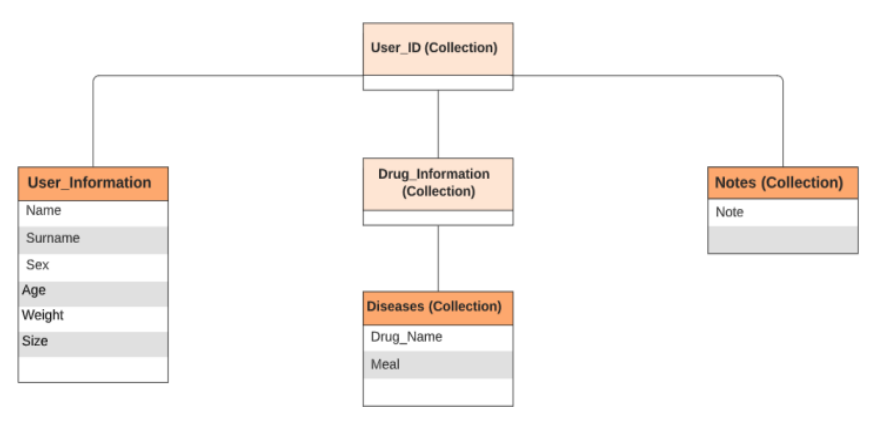

Figure3. Firebase Database Tree

The project has been developed in the Android Studio environment using object-oriented Java programming language. While developing the project, Agile software development method was used. Java classes, packages and architecture belonging to the prototype of the project are shown in Figure 4.

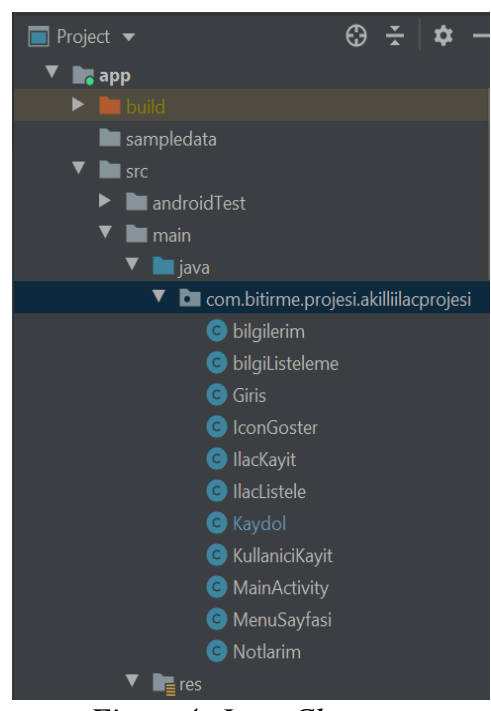

Figure4. Java Classes 


\subsubsection{Frontend Development}

In the developed prototype of the platform, it is determined whether the patient has taken the drugs that should be used, and the data is transferred to the application on the mobile phone. The data transferred to the application is also sent to the cloud from here and is stored permanently.

After downloading the application, the priority is to register on the Platform. During the registration process, the user completes the registration process by filling in the required information on the screen in Figure 5 (a). After the registration screen, the account in Figure 5 (b) is switched to login to the platform, and the login process is completed by entering the password information via e-mail.

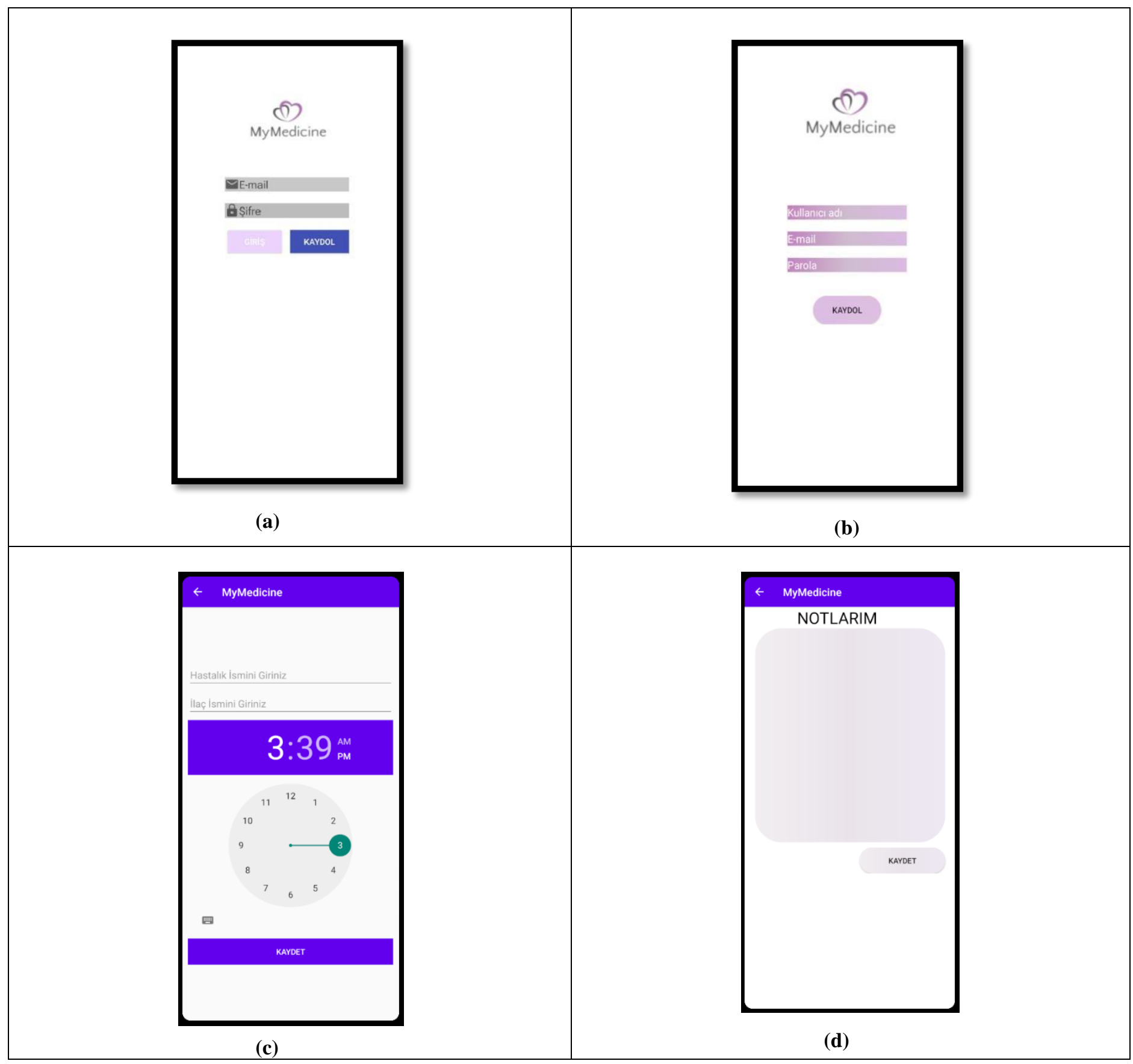

Figure5. Images Of Application 
After logging in, the menu page comes across and there are six action options in the menu formula. Personal information (name, surname, weight, height, age) is collected and recorded. In addition, the information entered in this section can be updated at any time with the update button. Add a new drug option has been added so that the user can add the desired drug. In this median, necessary information about the drug is taken and added for alarm. A monitoring program for drugs has been prepared. Here he comes across a calendar and can check the dates he wants. The medicines and diseases entered on my medications are listed. Finally, a section called My Notes has been created for the information that the person wants to receive for himself.

\section{Conclusion}

In this article, a prototype of a healthcare application developed for the field of health and using IoT technology is described. In the first prototype, a system that is open to everyone's use has been developed, which works as a mobile application that can be used by patients using regular medicines so that they do not forget their medicines. This system will also work integrated with the medicine box produced. During the development of the system, Java programming language was used as the application language for the services to be offered over the MyMedicine platform. Android Studio was used as the realization environment of the platform. The data are kept in the form of personal information, disease and medication information for each user in the database. Firebase Real Time Database is used as database. Users can receive instant notifications with the Notification feature of Firebase technology. Offering a simple and Turkish interface, the platform facilitates the use of elderly patients. With this platform, patients with serious illnesses will also have a personal health diary where they can easily follow their medication and track their illnesses. The notification feature, which is provided by the platform when the medication time comes, facilitates the intervention in advance and it is thought that vital situations can be prevented. In the later processes of the platform, it is planned to include the Covid19 drug tracking feature and a special system that makes daily recommendations in the Covid19 process. Thus, it is planned to be an online health platform that people who have been fighting the Covid19 virus, which has recently entered our lives, can use in this process.

\section{References}

Özgür A., Nurperihan K., (2019) Internet of Things Applications in Healthcare. Ubak International Academy of Sciences 2019/04/19, REPUBLIC 1. INTERNATIONAL SOCIAL SCIENCES CONGRESS

A. Y1lmaztürk, "Rational Drug Use in Turkey and the World", Journal of Kastamonu University Faculty of Economics and Administrative Sciences, c. 2, the number. 2, pp. 42-49, Jun. 2013

Özata, Musa: Aslan, Sebnem and Mete Mustafa (2008), "The Effects of Rational Drug Use on Patient Safety: Determining the Factors Affecting the Rational Use of Drugs by Physicians", II. International Patient Safety Congress, p.530

Islam SMR, Kwak D, Kabir MDH, Hossain M and Kwak K S. The Internet of Things for Health Care: A Comprehensive Survey. IEEE Access, Vol. 3, 2015; pp. 678-704.

Sezer, E., Ünalır, M., Yıldız, F., Gümüşkavak, A., Akçay, N .. (2018). Personalized Internet of Things Platform for
Healthcare. Academic Perspective Procedure, 1 (1), 311320. DOI: 10.33793 / acperpro.01.01.62

Dimitrov D. V. (2016). "Medical Internet of Things and Big Data in Healthcare", Healthcare informatics research, 22(3), p. 156-163.

GitHub, Last Access : 11 May 2021, Access Link: https://github.com/

Firebase, Last Access : 11 May 2021, Access Link: https://firebase.google.com/

Press Releases "Drug Use Behaviors" of our country were. (2009, 15 July) Access Link: http://www.ieis.org.tr/ieis/tr/press/14

Android Developers, Last Access : 11 May 2021 Access Link: https://developer.android.com/studio/features

Cingi, P. D., Erol, P. D. (1996). Pharmacology. T.R. Anadolu University Publications, p. 2. 